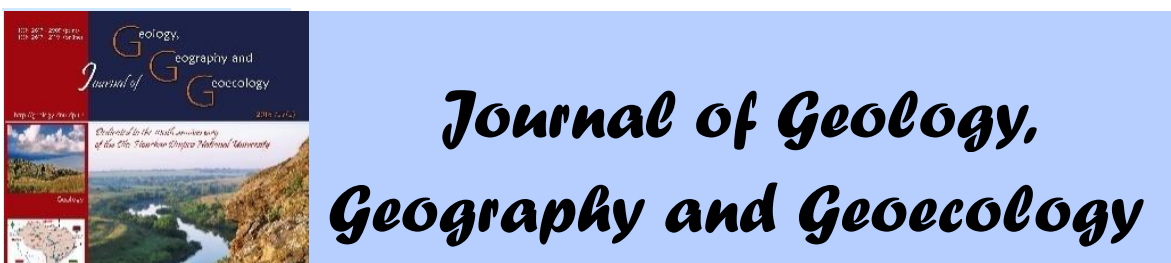

Journal home page: geology-dnu-dp.ua

\title{
Commercialization of the nature-resource potential of anthropogenic objects (on the example of exhausted mines and quarries)
}

\author{
S.E. Sardak ${ }^{1}$, O. P. Krupskyi ${ }^{1}$, S.I. Korotun ${ }^{2}$, D.E. Reshetniak ${ }^{1}$ \\ ${ }^{1}$ Oles Honchar Dnipro National University, Dnipro, Ukraine, e-mail:krupskyy71@gmail.com \\ ${ }^{2}$ National University of Water and Environmental Engineering, Rivne, Ukraine, e-mail: dnus@ukr.net
}

Received 12.11.2018;

Received in revised form 28.11 .2018 ;

Accepted 13.03.2019

Abstract. In this article we developed scientific and applied foundations of commercialization of the nature-resource potential of anthropogenic objects, on the example of exhausted mines. It is determined that the category of "anthropogenic object" can be considered in a narrow-applied sense, as specific anthropogenic objects to ensure the target needs, and in a broad theoretical sense, meaning everything that is created and changed by human influence, that is the objects of both artificial and natural origin. It was determined that problems of commercialization of the natural-resource potential of anthropogenic objects are most often considered by researchers for specific objects, without having complex methodological coverage from the point of view of combining environmental, technical, economic and managerial components. When studying the substantiation of the scientific base, the authors confirmed the feasibility of the commercialization of natural-resource potential of anthropogenic objects on the example of a number of theoretical scientific studies in reclamation, reconstruction, recreation, remediation, restoration of biological productivity and economic value of land disturbed by economic activity. The considered examples of exhausted mines in the 21 st century in the USA, Canada, Germany, Romania, and Poland indicate a wide range of opportunities for their commercialization. The study of the potential for commercialization of exhausted mines in the post-Soviet countries testified to the underused reserves for the commercialization of their nature-resource potential and their high potential for further development. The authors proposed the identification of anthropogenic objects on the basic livelihood spheres of society. There were identified the main system (natural, biological, technical, economic, social, managerial) and structural (subjects, trends, threats, risks, problems, challenges) factors of diagnosing the state of an anthropogenic object. A set of measures has been developed for commercialization of an anthropogenic object in functional and production activities, product policy, financial and investment spheres, pricing and sales policies, promotion, management and determination of property rights. Recommendations were provided on optimizing the management decision-making process based on a set of positivistic development principles, methods, and management functions. The study allows international organizations, state and local authorities, territorial communities, owners and potential investors to see new opportunities and make mutually beneficial decisions on the rational use of the nature-resource potential of anthropogenic objects.

Keywords: tourism, commercialization, investment, anthropogenic object, mines, reclamation.

\section{Комерціалізація природно-ресурсного потенціалу антропогенних об'сктів (на прикладі вироблених кар'єрів)}

\author{
С.Е. Сардак ${ }^{1}$, О.П. Крупський ${ }^{1}$, С.І. Коротун ${ }^{2}$, Д.С. Решетняк ${ }^{1}$
}

${ }^{1}$ Дніпровський начіональний університет імені Олеся Гончара, Дніпро, Украӥн, е-mail:krupskyy71@gmail.com ${ }^{2}$ Національний університет водного господарства та природокористування,Рівне,Україна. е-таі: dnus@ukr.net

Анотація. Розроблено науково-прикладні основи комерціалізації природо-ресурсного потенціалу антропогенних об'єктів, на прикладі вироблених кар'єрів. При вивченні наукової бази обгрунтування, автори отримали підтвердження про доцільність комерціалізації природо-ресурсного потенціалу антропогенних об'єктів на прикладі ряду теоретичних досліджень вчених в сферах рекультивації, реконструкції, рекреації, ремедіації, відновлення біологічної продуктивності та господарської цінності порушених земель, а також адаптації під економічно затребувані види господарської діяльності. Розглянуті приклади використання вироблених кар'єрів у XXI столітті в США, Канаді, Німеччині, Румунії та Польщі свідчать про широкий спектр можливостей їх комерціалізації. Вивчення потенційних можливостей комерціалізації вироблених кар'єрів на пострадянському просторі, засвідчило про наявність потенційних резервів комерціалізації природоресурсного потенціалу та високі потенційні можливості їх подальшого розвитку. Запропоновано авторську ідентифікацію 
антропогенних об'єктів по основним сферам життєзабезпечення потреб суспільства. Визначено головні системні (природні, біологічні, технічні, економічні, соціальні, управлінські) і структурні (суб'єкти, тенденції, загрози, ризики, проблеми, виклики) фактори діагностики стану антропогенного об'єкта. Розроблено комплекс заходів щодо комерціалізації антропогенного об'єкта в області функціональної і виробничої діяльності, товарної політики, фінансово-інвестиційній сфері, цінової і збутової політики, просування, управління і визначення права власності. Надано рекомендації щодо оптимізації процесу прийняття управлінських рішень на основі застосування набору позитивістських принципів розвитку, методів і функцій менеджменту. Дослідження дозволяє міжнародним організаціям, органам державної влади та місцевого самоврядування, територіальним громадам, власникам і потенційним інвесторам побачити нові можливості й прийняти взаємовигідні рішення в сфері раціонального використання природо-ресурсного потенціалу антропогенних об'єктів.

Ключові слова: туризм, комерцііалізація, інвестищї, антропогенний об'єкт, кар'єр, рекультивачія.

Introduction. The category "anthropogenic object" can be considered both in a narrow applied sense and in a broad theoretical one. For example, as the first approach, we can give a legislative definition when an anthropogenic object is interpreted as "aanthropogenic project to satisfy social needs and does not possess the properties of natural objects" (Federal Law, 2002). In the second approach, the value of the category "anthropogenic" is combined (changes in nature by human activity that affect the organic world) with "object" (phenomenon, object, person towards which/whom a certain activity, attention, is directed; the issue that is considered for the purpose of study or intended use). In this study, the authors use the "anthropogenic object" term in the second sense, meaning everything that was made, as well aschanged due to the influence of humans, that is, objects that are both artificially and naturally made. The objective of the research is to develop the scientific and applied foundations for the commercialization of the natural-resource potential of anthropogenic objects, on the example of exhausted quarries. To achieve the goal, the following aims were set and addressed in the paper: consideration of the forms of commercialization of anthropogenic objects; identification of anthropogenic objects by the spheres of livelihood needs of society; determination of the main system and structural factors of diagnosing the state of an anthropogenic object; development of a set of measures for the commercialization of an anthropogenic object.

Literature review. When studying the literature, the authors determined that the problem of the commercialization of the natural-resource potential of anthropogenic objects is most often considered by researchers for specific objects without a comprehensive methodological approachwhen combining environmental, technical, economic and managerial components. It is noted that the rapid growth of cities and industrial development lead to changes in the landscape and natural vegetation. Although in most cases post-industrial land is contaminated with various pollutants, in particular, xenobiotics, their close location to major cities in order to minimize the transportation cost of raw materials gives them considerable value.
The work of Ukrainian researchers, aimed at elaborating a ranking of countries in terms of sustainability of tourism, covers hazardous industries as a vital element in identifying the basic state of a country's sustainability. Improving the state of anthropogenic objects in this regard may also affect the country's overall position in the tourism services market (Stukalo et al., 2018).

Bauer, \& Ford (2014) note that the possibility of reconstruction and remediation of mines is determined by various factors: the physical properties of the rock, its size, depth, angle of the slopes' steepness and their stability, depth of groundwater.

Krinke (2001), indicates that in terms of increasing urbanization, such territories, after passing a number of relevant transformations, can be used for recreational and environmental purposes.

T.S. Chibrik, N.V. Lukina, E.I. Filimonova, M.A. Glazyrina, M.G. Rakov, M.N. Maleva, V. Prasad note that biological reclamation methods play a major role in restoring anthropogenically disturbed natural ecosystems, which use the basic principles of ecological successions that transform anthropogenic landscapes into productive territories suitable for forestry, agriculture and recreational zones (Bioremediation and Bioeconomy, 2016).

At the same time, Hüttl, Heinkele, \& Wisniewski (1996) note that remediation is considered as a set of measures aimed at realization of the maximum possible restoration of the biological productivity and economic value of disturbed lands.

Restoration of anthropogenically disturbed geo-ecosystems is a multidisciplinary and multilevel problem, whose solution is impossible without an integrated systems approach. Gunn (2012), notes that a systematic approach should include principles and methods of ecology, neo-ecology, environmental protection, remediation, economics, law, management, as well as take into account the natural, socio-economic and administrative features of the territory where restoration measures are carried out.

Fox, Moore, \& McIntosh (1998) draw attention to the fact that, depending on the initial 
quality, the location of land, and the degree of their anthropogenic disturbance, there are several areas of reclamation, which differ in their requirements: agricultural, forestry, water management, construction sanitary and hygienic, recreational and environmental protection.

Restoration of the natural potential of landscapes and ecosystems subjected to intensive anthropogenic pressure is the most important priority of the government strategies of developed countries. The environmental value of such projects cannot be overestimated, but their economic value is no less important in today's market conditions.

For instance, Shrestha and Mehmood (2018) examined the economic effect of the national project "Shortleaf-Bluestem Community Restoration Project", currently being implemented in the territory of the Ouachita National Forest (Arkansas and Oklahoma, USA). The authors showed that during the implementation of this project, 275 jobs were created, the budget surplus amounted to $\$ 14.6$ million. The study proved that the maximum economic effect is achieved at the regional level.

Exhausted quarries have great recultivation and commercial potential. The exhausted quarries offer ecological and educational opportunities: deep vertical slopes are convenient for studying geological sections of rocks, and can also serve as realistic habitats for petrophytes, for which artificial habitat creation is very labour intensive (Dal Sasso et al., 2012).

Mudroch et al. (2002) consider the feasibility of creating artificial lakes for recreational and environmental purposes in the cavities of exhausted mines for coal extraction.

Commercialization of mines reached a high level in the United States and Canada. In 1999, the Atlanta Beltline Project, a large-scale project for the reconstruction of a closed quarry for limestone extraction, was launched in Atlanta, Georgia. In 2006 , the quarry was bought by the city authorities to create a reservoir with a water supply for 30-50 days. Currently, work is continuing on filling the reservoir (Singleton et al., 2013).

Located in Portland, Connecticut, the private amusement park, Brownstone Exploration and Discovery Park, was established on the site of a closed limestone exhausted quarry in 2008. Limestone quarrying was discontinued in the 1930s when the quarry was flooded. Every year, 30-40 people died in its very cold waters. Attempts to drain the quarry were unsuccessful. In 2000, the Portland authorities rented the quarry hoping to improve the city's economic condition. In the adventure park, visitors are offered wakeboarding, climbing, swimming, kayaking, diving lessons, rope swings, water slides and inflatable water toys. It is estimated that 50 thousand people visit the park annually, which brings considerable income to the city budget and also provides for the creation of new jobs (Martin and Berlin, 2012).

Since 1989, Louisville, Kentucky, began the commercialization of the former limestone "Mega Cavern" mine. Currently, it has 12 enterprises. Caves left after limestone ore extraction are used for storage, processing, tourism (including tram, auto, bicycle and cable tours), contests, parties, shows (Louisville Mega Cavern, n.d.).

In Canada, on the island of Vancouver, the Butchart Gardens group of flower gardens has been set up in a mined-out limestone quarry, each offering a variety of cultural and entertainment activities: the annual Christmas light show, open-air concerts, boating, an ice rink, family restaurants and an amusement park. The flower gardens each year attract over 1 million visitors, create new jobs for local people, and reuse depleted land resources (Lyle, 2004).

In Cornwall (Great Britain), on the site of a former kaolin mining pit of 22,000 square meters "the Eden Projectwas implemented ". A botanical garden, was opened in 2001, with a set of domesgreenhouses, each of them artificially reproduced the climatic zones of the tropics and the Mediterranean and hundreds of different plant species were cultivated (Eden Project, n.d.). In addition to the cultivation of flora, guided tours are conducted in this complex, films are made, and concerts are held.

Since 1992, sightseers have been admitted to a former salt mine in Transylvania (Romania)and in 2010, the Salina Turda attraction, located at a depth of 120 meters, was opened, offering mini golf, a movie theater, a ferris wheel and a boat station. There is also an above ground complex with a beach at the open-air salt lakes - "Durgau Strand" and SPA-center (Salina Turda) nearby. Up to now, these underground and aboveground complexes have been visited by more than 2 million tourists.

A famous example of the successful application of biological remediation on a large scale is the Rhenish region (Germany), where 30 thousand hectares of the landscape disturbed during the development of lignite deposits were restored. The solution of this problem significantly optimized the methodology for correcting environmental and economic problems in such situations. The results of this work showed that landscape restoration is a process that allows further optimal use of anthropogenically disturbed areas from the biodiversity conservation, as well as the recreational and economic points of view (Eßer et al., 2017). 
Successful examples of reclamation of mined-our quarries can be found in Poland near Krakow. From the beginning of the 19th century, on the Wawel Hill slope, limestone was mined by quarrying. The developed rock formation forms an aesthetic composition with fortifications, that are located on the hill top, as well as the undisturbed part of the slope, as its natural continuation. The rock formation creates a harmonious background for the sculpture installed here of the Wawel Dragon (Górecki\&Sermet, 2010; Luc \&Szmańda, 2015). On the northern slope of the Lazot Hill in Krakow, there is the old SzkołaTwardowskiego quarry, named after the local teacher WojciechBednarski, whose initiative was that the site of limestone production, which had already ceased by the end of the 19th century,was turned into a recreational park. Exposed limestone rock outlines the boundaries of the park, representing a picturesque landscape element (Górecki\&Sermet, 2010; Luc \&Szmańda, 2014). Wieliczka Salt Mine, a popular former salt cave, is located in Wieliczka, thirty minutes from Kraków city. In 1978, it entered the UNESCO List of World Cultural and Natural Heritage. It has nine floors, a total length of about 250 kilometers extending to a depth of 327 meters. There is a museum, presenting salt sculptures, a chapel, and a trampoline in the cave. So far, this complex has been visited by 43 million tourists (Wieliczka-saltmine.com, n.d.).

In the countries of the former USSR, the commercialization of the natural-resource potential of anthropogenic objects is local and has not received worldwide popularity. Moreover, there is no information about examples of commercialization of exhausted mines and quarries in scientific and official sources. Therefore, the authors provide information collected on the basis of a personal visit to the objects and a description made by experts on these sites.

For example, in Belarus, near Khotinovo village, Lyubansky district, Minsk region, at the end of the twentieth century, lime production in a quarry 30 meters deep was stopped and a lake with clear water formed on the territory of a chalk pit. After the cessation of its original use and the attendant security regime, 10 people drowned and the territory began to be polluted by tourists. In 2017, the territory was leased through a state auction for the purpose of organizing a beach area and building guest houses, a restaurant, a bathhouse and a camping site.

In Ukraine, in Nikopol district of Dnepropetrovsk region, on the edge of Starozavodskoye village, at an exhausted mine, a Ukrainian-Chinese group of investors and engineers is embodying a project to create a solar power station with a capacity of $200 \mathrm{MW}$. The project cost is 230 million Euros. The power plant will provide about 100 thousand households and industrial facilities with clean energy.

In the city of Dnipro (Ukraine) in the Krasnyi Kamine residential area a20-30 m deep quarry for granite extraction was closed in the middle of the twentieth century due to the influx of groundwater. A lake formed where locals began to swim and fish. In the early 1980s the state improved the beach and recreation areas and installed a fountain. However, subsequently the regular cleaning of the territory ceased. In 2010, local government carried out a cleaning operation and in 2011 a beach and commercial infrastructure were officially opened on a rental basis, but the problem of commercialization and restoration of vegetation was not completely resolved and a year later the beach was closed again and several people drown there every year. Also in the city of Dnipro on the site of a former quarry for the sand extraction on Journalists Street a lake formed, which operates as a spontaneous beach with elements of the recreation and entertainment industry ( catamaran and boat rides, cafes).

In Elizavetovka village, Petrikovsky district of Dnepropetrovsk region (Ukraine), there is a former "ElizavetovskyPit" - a quarry for the sand extraction about 20 meters deep, which was flooded in the 1970s with fresh blue water and is popularly referred to as "The Blue Lake". At the beginning of the second decade of the XXI century the area around the lake was rented by several entrepreneurs who equipped it with a beach infrastructure, an amusement park, boat rental, shops, cafes, camping sites and bathing facilities for thousands of tourists.

Near Shchurovo village, Krasnolimansky district, Donetsk region (Ukraine), in the 1960s sand mines were flooded and blue lakes with spring water were formed. In recent years, beaches have been equipped and comfortable recreation centers have been built there, which attracts tourists all the year round.

In Khotyn village, Rivne region (Ukraine), a cascade of clay mining mines was abandoned and flooded from natural sources, as early as the early 1980s . All the mines have long been measured by echo sounders and have an average depth of six, and in deep places up to ten meters. One of the mines is now privatized and work has begun on recreationalisation of the territory. Vacationers can also swim in the Horyn river, which is connected to the mines.

Near Oleshnya village, Repkinsky district, Chernihiv region (Ukraine), there are 3 lakes with clear blue water, formed as a result of flooding of 20meter sand quarries. Currently, recreation centers and 
campsites of that place are visited by over 250 thousand tourists from Ukraine, Russia and Belarus every year.

Near Slavuta town, Slavuta district of Khmelnitsky region (Ukraine), 5 artificial reservoirs were formed at a worked-outpeat extraction site. A tourist base has been built near Strigany village. The lake cascade is part of a hydrological reserve with the same name "Blue Lake". Green tourism is developing in the surrounding villages. On hot summer days there are a lot of tourists, who mostly come by car.

In Kryvyi Rih city (Ukraine) at the end of the twentieth century 2 granite mines: "Karachunovsky" and "Oktyabrsky" were flooded. The resulting artificial lakes with clean water of greenish color are visited by local residents, diving is actively developing, and competitions in extreme cycling are held in the adjacent territory. Also, new species of birds have began to arrive here, which attracted the attention of ornithologists.

Methods and materials. For the development of scientific and applied foundations of the commercialization of the natural-resource potential of anthropogenic objects, the author applied a methodology that provides for a phased implementation of procedures: identification of the anthropogenic object (according to 7 defined areas of the author's classification); diagnostics of the state of the anthropogenic object (according to 36 features influenced by systemic and structural factors); the development of a set of measures for the commercialization of an anthropogenic object (in functional and production activities, product policy, financial and investment spheres, price and sales policy, promotion, management and determination of property rights) by optimizing the management decision-making process based on the set of positivistic development principles, methods and functions of management.

Results. As a result of the study of existing anthropogenic objects, the authors stated the limitations of their aims. As an "anthropogenic object"category, as a rule, anthropogenically transformed landscapes areconsidered. In this case, there are several stages oflandscape change, which are differentiated depending on the ratio of natural and anthropogenic elements. In terms ofanthropogenic pressure on components of the natural environment the landscapes are classified as follows: primary landscapes, natural, culturally harmonious, culturally disharmonious, culturally degraded and devastated landscapes. The first three landscapes categories are sustainable; therefore the landscape management goal is to restore the natural balance in the disturbed ecosystems (Lucetal., 2015).
The authors propose their classification of anthropogenic objects by highlighting seven areas of life support of society's needs:

1. Objects created for military purposes and to ensure domestic order where equipment and people are located (e.g., military base, firing range, fortress, defensive structure, tower, vault, prison, large warship, observation tower, etc.);

2. Objects created for production and household activities in the areas of: mining (e.g., a mine, a quarry, a drilling platform, a floating base, a land exploration mechanism); processing (e.g., plant, mining and processing plant); transportation (vehicle, transport mechanism, transmission device); recycling (e.g., landfill, burial ground);

3. Infrastructure facilities and ancillary facilities (e,g., road, bridge, dam, embankment, port, airfield, terminal, platform, pipeline, etc.);

4. Residential buildings where people are accommodated on a voluntary permanent or temporary basis (e.g., a residential building, a hotel, a hospital, hospice, etc.);

5. Objects created for public communications and services (e.g., institution, shop, office, stadium, church, museum, service company, concert hall, etc.);

6. Memorial facilities (e.g., a park, a monument, a cemetery, etc.);

7. Landscape objects (e.g., land, coastal zone, spit, beach, lake, river, island, etc.).

This classification does not take into account the forms of ownership of specific anthropogenic objects, their belonging to the public or private sector, and whether they are profitable and subsidized. The classification is aimed at delineating the "scope" and the circle of experts who can be involved in further work on the commercialization of an anthropogenic object. The identification of the belonging of an anthropogenic object to the above areas allows more effective carrying out of the diagnostic procedure by selecting adequate experts (including marketing specialists, technical specialists, economists, lawyers, project managers) and conducting of necessary expert evaluations.

Diagnostics of the state of an anthropogenic object involves an individual assessment procedure, including consideration of a wide range of influencing factors. Generally, the main factors influencing the development of an anthropogenic object can be represented as two groups. The first group is systemic factors (due to the influence of natural, biological, technical, economic, social, and managerial systems). The second group is structural factors (subjects, trends, threats, risks, problems and challenges that exist in the external and internal environments of the object). When using the matrix method, factors for the development of an anthropogenic object can be visualized as shown in Table 1 . 
Table 1. Main factors in the development of an anthropogenic object*

\begin{tabular}{|l|c|c|c|c|c|c|}
\hline Factors & Subjects & Trends & Threats & Risks & Problems & Challenges \\
\hline Natural & NS & NT & NTh & NR & NP & NC \\
\hline Biological & BS & BT & BTh & BR & BP & BC \\
\hline Technical & TS & TT & TTh & TR & TP & TC \\
\hline Economic & ES & ET & ETh & ER & EP & EC \\
\hline Social & SS & ST & STh & SR & SP & SC \\
\hline Managerial & MS & MT & MTh & MR & MP & MC \\
\hline
\end{tabular}

* developed by the authors based on (Sardak et al, 2017).

By using this methodological approach, expert groups can identify 36 characteristics of the state of an anthropogenic object, which will help to objectively determine its condition and draw the conclusion whether:

1. The object performs and can further perform its intended purpose with adequate resource support;

2. The object does not perform its intended purpose, but can resume the performance of its intended purpose with adequate resource support;

3 . The object does not perform its intended purpose and is not suitable for the resumption of performance of its intended purpose.

After the conclusion of diagnosis of a anthropogenic object, one can further develop the set of measures for the commercialization of its natural resource potential, which provides for a number of possible actions of the owners in different areas of economic activity, taking into account the life cycle elements: pre-system state, growth, stabilization, reduction, post-system state (Sardak, 2016). So, for instance, we outline key permanent spheres of economic activity of the owners ofanthropogenic objects.

functional activity: to continue operation of the facility in the format of its intended purpose; transform to another target area; preserve the object; eliminate it (destruction or recycling);

production activities: change and adaptation of technology, equipment replacement, activation of scientific and technical creativity and staff rationalization;

product policy: retain the existing set of objective functions; expand the set of target functions with the implementation of a new range of goods and services (rental of the object, security, purification, cleaning, repair, saving, recycling, etc.); sale of available resources;

financial policy: conduct a financial audit, reallocate financing of processes and resources, optimize the financial resourcestructure;

investment policy: developing a new investment policy, intensifying the search for national and international investors, attracting credit funds and sponsorship; implementation of crowdfunding; attraction of subsidized funds from government agencies and international organizations;

pricing policy: changing or combining existing pricing of both methods and strategies;

sales policy: change or expansion of forms of commercialization: wholesale; retail; direct marketing; contractual systems of distribution of goods (network marketing, franchising, leasing, tolling); special forms of market presentation and sale of goods (fairs, exhibitions, commodity exchanges, trading houses, auctions, tenders); rent; online trading;

promotion: expansion and intensification actions in advertising, public relations, sales promotion and personal actions of personnel;

management and ownership: determining the appropriateness of a change of ownership, which provides further independent management, cooperation (attracting partners, selling shares, creating joint ventures and other forms of cooperation) or selling an object;

management and organization: management system optimization, replacement of management personnel, facility administration optimization;

information support: optimize the system for monitoring, analyzing and storing information, streamlining workflow;

interaction with state and local authorities: establishing long-term contacts, familiarizing with the prospect of changing the policy of using anthropogenic objects, entering into contractual obligations, forming associative structures, and political lobbying of interests.

Discussion. In the twenty-first century development of a complex of measures for the commercialization of the natural resource potential of an anthropogenic object involves management decisions based on the application of: positivistic development principles (scientific management, ecology and environmentalism, green economy, sustainable development, effective international organizations states and enterprises); management methods (first of all: systems approach, analysis, synthesis, analogies, generalization, simulation, idealization, abstraction); management functions (including: information support, planning, forecasting, programming, coordination, organization, 
motivation, control and regulation) ("Zelena" ekonomika, 2018).

For example, with the commercialization of the exhausted flooded mines by owners, the promising areas may be: obtaining funds from local governments, territorial communities and international organizations for cleaning, improvement and protection; lease of territory to entrepreneurs; rental of beach and diving equipment for travelers; construction of facilities and provision of services such as hotels, restaurants, gaming, sports and medical-recreational industry; guided tours; conducting competitions; event organization (event tourism) - holding birthday parties, weddings, festivals, etc.; making films and TV programmes for broadcast in the media; the creation of protected areas.

When commercializing the exhausted mines by owners, the promising areas may be: transformation into field testing sites (military, research, civilian); the storage of waste and garbage that does not threaten the environment of the disposal area (permanent, temporary or technological for subsequent removal); organization of processing industries (processing, grinding, recycling); organization of industrial and extreme tourism (excursions, creation of viewing platforms, carrying out photo shoots and reportage, paid cable descents and jumps); holding art events (shooting films, programmes, concerts, competitions); holding sporting events (sports tourism, orienteering, mountaineering competitions, paintball).

It must be borne in mind that measures for the commercialization of anthropogenically disturbed ecosystems that are not properly developed within the systems approach concept, involving cooperation and coordination of efforts by a large number of partners and investors, can only worsen the condition of such facilities (Gustafson, 2000). The most effective are long-term integrated recovery methods, containing environmental, managerial, legal, financial, social and technological aspects of the impact. The high success of such methods, including planning, monitoring and evaluating the current state of the object, becomes apparent only a few years after the start of their use (Sapkota et al., 2018).

Conclusions. The considered examples show how the recultivation, remediation, reconstruction and subsequent commercial use of anthropogenically transformed landscapes; exhausted minesand quarries in particular, contribute to the economic and cultural development of the surroundingterritories. By contributing to the restoration of land disturbed by mining and depositing of construction waste, it is possible to neutralize the effects of industrial activity and reduce the negative impact of mines on the environment.

The study of the identification issues of anthropogenic objects, diagnosis and development of a set of commercialization measures allows international organizations, state and local authorities, territorial communities, owners and potential investors to see new opportunities and make mutually beneficial solutions in the rational use of natural resources of anthropogenic objects.

\section{References}

Bauer, A.M., Ford, R.E. (2014). Reclamation planning of pits and mines. Landscape Architecture, 104(7), 146-149.

Bioremediation and Bioeconomy.

(2016). doi:10.1016/c2014-0-02734-7.

Dal Sasso, P., Ottolino, M. A., \&Caliandro, L. P. (2012). Identification of Mines Rehabilitation Scenarios: A Case Study Within the Metropolitan Area of Bari (Italy). Environmental Management, 49(6), 1174-1191. doi:10.1007/s00267-012-9847-0.

Eden Project. (n.d.). Retrieved October 11, 2018. Access mode: https://www.edenproject.com/. - Title from screen.

Eßer, G., Janz, S., \& Walther, H. (2017). Promoting biodiversity in recultivating the Rhenish lignitemining area. World of Mining -Surface and Underground, 69(6), 327-334.

Federal Law of the Russian Federation "On Environmental Protection" № 7-Ф3 from 10.01.2002. - Access mode: http://extwprlegs1.fao.org/docs/pdf/rus52751E.pd f. - Title from screen.

Fox, H. R., Moore, H. M., \& McIntosh, A. D. (1998). Land reclamation: achieving sustainable benefits.

Górecki, J., \&Sermet, E. (2010). Kamieniołomy Krakowa-dziedzictwoniedocenione [Mines of Krakow - an underestimated heritage]. W: Zagożdżon, P., Madziarz, M.,(eds), Dziejegórnictwa-element europejskie godziedzictwa kultury, 3, 123-138 (in Polish).

Gunn, J. M. (Ed.) (2012). Restoration and recovery of an industrial region: progress in restoring the smelter-damaged landscape near Sudbury, Canada. Springer Science \& Business Media.

Gustafson, A. (2000). Making sense of postmodern business ethics. Business Ethics Quarterly, 10(3), 654-658. doi:10.2307/3857896.

Hüttl, R. F., Heinkele, T., \& Wisniewski, J. (Eds.). (1996). MinesiteRecultivation. doi:10.1007/97894-015-8694-8

Krinke, R. (2001). Overview: design practice and manufactured sites. Manufactured sites: Rethinking the post-industrial landscape, 125-149.

Louisville Mega Cavern. (n.d.). Retrieved October 10, 2018. Access mode: https://louisvillemegacavern.com/. - Title from screen.

Luc, M., \& Szmańda, J. (2014). Should renaturalised and recultivated landscapes appear in landscape 
typology? QuaestionesGeographicae, 33(3), 6575. doi 10.2478/quageo-2014-0030.

Luc, M., \& Szmańda, J. B. (2015). Renaturalized and Recultivated Landscapes as a Result of Sustainable Landscape Management. Landscape Analysis and Planning, 271-292. doi:10.1007/978-3-319-13527-4_16.

Lyle, D. (2004). Butchart Gardens. The Public Historian, 26(4), 88-90. doi: 10.1525/tph.2004.26.4.88.

Martin, D., \& Berlin, H. (2012). Mines Next Quest. Planning, 78(2), 40-42.

Mudroch, A., Stottmeister, U., Kennedy, C., \&Klapper, H. (Eds.) (2002). Remediation of Abandoned Surface Coal Mining Sites: A NATO-Project. Springer Science \& Business Media.

Salina Turda (n.d.). Retrieved October 18, 2018. Access mode: http://salinaturda.eu/. - Title from screen.

Sapkota, R. P., Stahl, P. D., \&Rijal, K. (2018). Restoration governance: An integrated approach towards sustainably restoring degraded ecosystems. Environmental Development, 27, 8394. doi:10.1016/j.envdev.2018.07.001.

Sardak, S. (2016). The life cycle of social and economic systems. Marketing and Management of Innovations, 1, 157-169. (in Ukrainian).

Sardak, S., Korneyev, M., Simakhova, A., \&Bilskaya, O. (2017). Global factors which influence the directions of social development. Problems and
Perspectives in Management, 15(3), 323-333. doi:http://10.21511/ppm.15(3-2).2017.02.

Shrestha, A., \&Mehmood, S. R. (2018). Economic Impacts of the Shortleaf-Bluestem Community Restoration Project. Journal of Forestry, 116(6), 505-512. doi:10.1093/jofore/fvy038.

Singleton, V. L., Jacob, B., Feeney, M. T., \& Little, J. C. (2013). Modeling a Proposed Quarry Reservoir for Raw Water Storage in Atlanta, Georgia. Journal of Environmental Engineering, 139(1), 70-78. doi:10.1061/(asce)ee.1943-7870.0000582.

Stukalo, N. V., Krasnikova, N. A., Krupskyi, O. P., \&Redko, V. Y. (2018). Fostering Sustainable Tourism in Global Economy. Revista ESPACIOS, 39(42). Retrieved October 18, 2018. - Access mode:

http://www.revistaespacios.com/a18v39n42/1839 4227.html.

Wieliczka-saltmine.com. (n.d.). Tourist Route: "Wieliczka" Salt Mine. Retrieved October 16, 2018. Access mode: https://www.wieliczkasaltmine.com/visiting/tourist-route. - Title from screen.

«Zelena» ekonomika: vid hlobal'noyikontseptsiyi do realiymistsevohorozvytku [«Green» economy: from global concept to reality of local development]. (2018). Dnipro, Ukraine: Serednyak. doi:10.5281/zenodo.1294014 (in Ukrainian). 